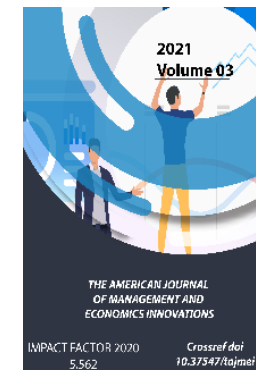

Journal Website: https://theamericanjou rnals.com/index.php/ta jmei

Copyright: Original content from this work may be used under the terms of the creative commons attributes 4.0 licence.

\section{An Economic System And Its Elements}

\author{
Nazarova Charos Bahodir Qizi \\ Associate Professor, PhD, Tashkent University Of Information Technologies, Named After, \\ Muhammad Al-Khwarizmi, Uzbekistan
}

\section{Nazarova Gulchexra Nurmuxanbetovna}

Associate Professor, PhD, Tashkent University Of Information Technologies, Named After, Muhammad Al-Khwarizmi, Uzbekistan

\title{
ABSTRACT
}

An economic system is a set of interrelated elements that make up a common economic structure. It is common to distinguish 4 types of economic structures: traditional economy, command economy, market economy and mixed economy. The following article discusses all the four types of an economic system.

\section{KEYWORDS}

Traditional Economy, Command Economy, Market, Production.

\section{INTRODUCTION}

Traditional economy is based on natural production. There is usually a strong agricultural bias. The traditional economy is characterized by clan, legalized property, caste division, and separation from the outside world. In a traditional economy, customs and unspoken laws are strong. Personal development is very limited in a traditional economy and it is almost impossible to move from one social group to another that is high in the social pyramid. Traditional economies often use exchange instead of money.
In such a society, the development of technology is very slow. Now there are almost no countries with traditional economies. Although in some countries it is possible to distinguish isolated communities that lead a traditional lifestyle, such as tribes in Africa, they lead a lifestyle that is not much different from their distant ancestors. Nevertheless, in any modern society, the remnants of ancestral traditions are still preserved. For example, it could be about celebrating religious holidays like Christmas. In addition, the division of 
professions into male and female still exists. All these traditions are reflected in the economy in one way or another.

Command economy Command or planned economy is characterized by the centralized decision of what, how, for whom and when production. Demand for goods and services is determined on the basis of statistics and plans of the country's leadership. The administrative economy is characterized by high production and concentration of monopolies. Factors of production are almost excluded from private ownership or there are major barriers to the development of private business. In a planned economy, a crisis of overproduction is unlikely. There is a high probability of a shortage of quality goods and services. Indeed, why build two shops next to you or why you need to develop advanced equipment in the production of poor quality equipment - there is still no alternative. Of the positive aspects of the planned economy, it is necessary to emphasize the saving of resources, especially human resources. In addition, the planned economy is characterized by a rapid response to unexpected threats - both economic and military (remember how quickly the Soviet Union managed to evacuate its factories to the east of the country, which cannot be repeated in a market economy).

\section{MATERIALS AND METHODS}

\section{MARKET ECONOMY}

Market economy ... The market economic system, unlike command, is based on the predominance of private property and free pricing based on supply and demand. The state does not play an important role in the economy, its role is limited to regulating the situation in the economy by law. The state only ensures that these laws are observed, and any disturbances in the economy are quickly rectified by the "invisible hand of the market".

For a long time, economists considered government intervention in the economy to be harmful and argued that the market could selfregulate without external intervention. however, the Great Depression denied this claim. The point is that the crisis could be overcome only if there was a demand for goods and services. And since no group of economic entities could form this demand, demand could only arise by the state. That is why, in times of crisis, states begin to re-equip their armies - thereby creating a basic demand that will revitalize the entire economy and allow it to get out of the vicious circle. Mixed economy ... There are almost no countries with only market or command or traditional economy. Every modern economy has elements of both a market and a planned economy, and of course there are remnants of a traditional economy in every country. The consumer sector is almost entirely owned by private companies because they can better identify the demand for their products, as well as see new trends in a timely manner. But some goods can only be produced in a traditional economy - folk costumes, some food products, etc., so elements of the traditional economy are preserved.

The concept of the economic system of society, its structure

The Greek word system means a whole made up of parts. The economic system was first considered by Adam Smith in 1776. There are different approaches to defining an economic system, e.g:

The economic system is this method of production, ie. the unity of the productive forces and the corresponding production relations (this is the Marxist approach); or this 
community of people (society) united by common economic interests; or this is the unity of human and social production, and so on.

Economic system is a set of principles, rules and legally established norms that determine the form and content of economic relations in the production, distribution, exchange and consumption of economic goods in the country.

The economic system of a society consists of interdependent and interacting elements. These elements form the structure of the economic system.

The structure of the economic system:

- $\quad$ Productive forces;

- $\quad$ Production relations;

- $\quad$ Management system.

Consider the structural elements of an economic system.Productive forces are a set of material and personal factors of production and certain forms that ensure the interaction and efficiency of their use.

Elements of productive forces:

means of production, ie. means of labor (what the activity is done with) and objects of labor (what the activity is focused on).

Structure of productive forces:

Material - a set of personal and material factors of production. The means of production are put into production by people, so the main productive force is people with experience and skill.Types of production relations:

between countries (international production relations);
The subjects of industrial relations are labor communities, individuals, social groups, society.

Types of production relations:

- Between countries (international production relations);

- Between the state and firms (enterprises);

- $\quad$ Between enterprises;

- $\quad$ Between the state and households;

- Within the enterprise;

- Between businesses and households.

\section{DISCUSSIONS AND RESULTS}

Any economic system has a national mechanism of its activity. What is a system of governance - a set of governing bodies and regulating the economy of a particular country, group of countries? It includes property relations, coordination mechanism and level of regulation by the state.

Types of economic systems

Different methods and approaches to the classification of economic systems are known in the history of economics. According to Karl Marx, economic systems are divided according to socio-economic formations: primitive, slave, feudal, capitalist and communist. This is related to the level of development of the productive forces that preceded the development of production relations. Conflicts between productive forces and production relations can lead to conflicts, resulting in a change in formation.

\section{REFERENCES}

1. A NEW STAGE OF REFORMING THE TRAINING OF LEGAL PERSONNEL. $F$ Mukhitdinova Review of law sciences 2 (1), 2017. 
2. Ideas and teachings on the concept of spiritual and moral education of the younger generation in Uzbekistan FA Mukhitdinova, SS Agzamkhodzhayeva Eurasian Union of Scientists, 2019.

3. Problems of power and management in the works of Eastern thinkers FA Mukhitdinova, HMM Mukhammedov High School, 35-38, 2015.

4. Implementation of human rights protection in Uzbekistan IV Kudryavtsev Eurasian Union of Scientists, 2019.

5. The origins of the idea of civil society FA Mukhitdinova, IN Kudryavtsev ACTUAL ASPECTS OF MODERN SCIENCE, 102-109, 2017. 